DOI: $10.17516 / 1997-1370-0551$

УДК 304.2

\title{
Place of Mediation in the Monitoring of the Educational Process Conflict Factors in the Conditions of Modern Risks
}

\author{
Anna G. Pinkevich and George P. Artemov \\ Saint-Petersburg State University \\ St. Petersburg, Russian Federation
}

Received 04.01.2020, received in revised form 09.01.2020, accepted 12.02.2020

\begin{abstract}
This article deals with the role of mediation in conflict management and especially in the monitoring of conflict factors of education activities.

In the article the authors analyse the system of monitoring and its principles and methods. Special attention is paid to the integration of monitoring and mediation.

Recently, the mediation institution has been developing quite actively in Russia. Mediation is a negotiation with a third neutral party. It differs from negotiations by the removal of responsibility for carrying out procedures from representatives of the parties. It is one of the ways of conflict prevention and regulation.

The article shows different models of embedding of mediation into the conflict management system in high school. Mediation and monitoring are considered as important parts of this management.
\end{abstract}

Keywords: conflict factors, mediation, education, risks, monitoring.

This article is supported by the Russian Science Foundation (RSF No. 19-18-00115) "Risk reflection in modern Russian conflict management strategies".

Research area: education.

Citation: Pinkevich, A.G., Artemov, G.P. (2020). Place of mediation in the monitoring of the educational process conflict factors in the conditions of modern risks. J. Sib. Fed. Univ. Humanit. Soc. Sci., 13(2), 201-207. DOI: 10.17516/1997-1370-0551.

(C) Siberian Federal University. All rights reserved

* Corresponding author E-mail address: a.pinkevich@spbu.ru

ORCID: 0000-0003-4282-4967 (Pinkevich); 0000-0003-0794-0719 (Artemov) 


\section{Introduction}

Risks are an integral part of the society development. Moreover, they carry the probability of losses and gains. "A general risk assessment is interpreted through a self-assessment of the safety of the environment, vulnerability to various risks, and risk preparedness" (Shlykova, 2015: 5). Perception of risks, readiness for them is an important factor in the functioning of modern society, institutions, social strata, individuals. Education, as one of the most important institutions of our time, is also affected by various risks. The ability to identify them, respond to them, the level of their negative consequences is part of the activity to ensure positive dynamics in the development of the educational institution. Any other area of academic research and public debate can hardly compete with the degree of attention of domestic authors to the problems of the content and consequences of the Russian system of higher education reform. However, there is no full agreement on the key parameters of the problems of educational activity of higher educational institutions, its components, indicators and consequences, including the conflictological context (Vol'chik, 2013; Kuz'minov, 2002; Kurbatova, 2016; Titova, 2008). Following George Ritzer (Ritzer, 2011), it became fashionable to talk about the "McDonaldization" of educational activity when the goal-oriented principles of the famous fast food become the methodological basis for organising modern universities (Kil'dyushov, 2016). A number of analysts insist on the imitational nature of the national reform of higher education (Tambovtsev, Rozhdestvenskaya, 2014).

An important component of these processes is a system for monitoring the conflict factors of educational activity. Conflicts frequently occur in university campuses but it is possible and even necessary to manage them. Collecting data is an important part of all conflict management system. In order to make decisions, one should have objective information about all indicators of the education process. Conflict management system consists not only of the applied studies but it also includes recommendation for the conflict management and actually the management action itself.
This article deals with the higher education institutions. The main goal is to understand which place mediation can take in the monitoring of conflict factors in the education process. In order to succeed in implementation of these goals it should involve "research, educational courses, and practice in conflict resolution, and the use of mediation as a dispute system alternative" (Katz, 2016: 177). Therefore, conflict prevention and resolution is one of the element of the system and mediation is one of the methods of conflict management.

\section{Theoretical framework}

There are different theoretical methodological and empirical approaches to the conceptualisation of many problems of educational activity of higher educational institutions. Nevertheless, these discussions allow to outline one common key point - educational reform is an additional conflict-generating factor in the social and political life of modern Russia and "is a structurally and functionally complicated phenomenon in which conflicting strategies of internal and external cultural changes come together" (Karpov, 2015: 11).

The research literature presents several approaches to the topic of conflict factors in educational activities. Some authors analyse the educational process in schools and universities, and at the same time pay attention to conflict determinants (Character development in schools, 1992; Tavokin, 2012). Others consider individual elements of the educational process, for example, the relationship of students and teachers (Wyrick, 2011; Clark, 2014; Hamre, Pianta, 2006; Ignatova, 2014; Vinokurov, Potapov, 2004). A number of works are devoted specifically to conflicts in educational activities and universities (Vinogradova, Kozina, 2011; Ryapisov, Ryapisova, 2016), as well as the influence of individual factors on the educational process and its elements (Banikina, Stepanov, 2016). There are works devoted to the educational process monitoring (Chepel, Abakirova, Samuylenko, 2014). The listed theoretical base allows us to analyse the educational process from the standpoint of a rather complex and well-developed conflict research methodology. 
In domestic literature many authors pay attention to the process of mediation development in schools (Petrova, Plotnikova, 2017; Chupris, 2016; Konovalov, 2014) and less write about mediation in higher educational intitutions (Ryabinina, 2015). More attention is paid to the mediation in universities in other countries (Yarn, 2014; Klingel, Maffie, 2011; Katz, 2016). The reason of this situation is that using of mediation in school and interest to the conflicts in school from our point of view is much bigger than to those in higher education institutions. Institutionalisation of mediation in school is developed today much better than in universities. This is mainly due to the authorities' attention to conflicts in schools.

It is necessary to clarify that the presence of conflict factors does not necessarily lead to conflicts and conflict interaction. Only under a certain set of circumstances and in the presence of certain conditions does a conflict situation turn into a conflict. It is important and possible to prevent this process, and this is one of the tasks of conflict management. However, the concept of conflict management is somewhat broader than just preventing conflicts. Conflict management is understood as a deliberate impact on their dynamics. This effect can be carried out at different stages of the conflict development: at the stage of origin, the formation of a conflict situation; at the stage of conflict interaction; at the stage of completion of a conflict. Conflict management elements include prevention, mitigation, incentives, regulation and resolution. The earlier the actions to manage the conflict are taken, the higher the likelihood of their effectiveness.

\section{Research Results}

Monitoring the conflict factors in the educational process should be a sort of special system. This system includes activities to collect empirical data and recommendations for conflict management. Moreover, this monitoring in its turn is a necessary element of the whole system of conflict management. Monitoring of conflict situations involves a system of periodic applied research, in order to ensure the constant flow of information about the phenomena studied. It implies the allocation of a limited number of the most significant indicators reflecting the situation at the university. Monitoring means that there should be repeated measurements of indicators. This monitoring can be carried out at least once a year.

Monitoring may include quantitative and qualitative methods for collecting information. Among the quantitative ones, we recommend the questionnaire, since it allows one to increase the level of anonymity in obtaining information in organisations and small groups. The toolkit should include an invariable part and block, which can vary from research to research and study the aspects of the problem that are relevant at the time of the study. Qualitative methods are important for a more indepth interpretation of quantitative data. Here one can recommend focus groups and in-depth interviews. The latter does not provide us with representative information, but allows to look deeper into the problem, which enriches its interpretation. An expert survey is also advisable in this situation, which can also contribute to the analysis of the data obtained. Experts in this area can be representatives of the educational process, researchers in this area, officials. Subjects of educational activity are subject of the research: students, lecturers, teaching support and administrative staff. All of them are the main participants in educational activities.

Not only conflict factors of the education process can be the aim of the monitoring but already mediation itself. We mean that mediation as a technology of conflict management and prevention can have some problems during its inculcation. This problem exists in our education at different levels - in schools, universities etc. Nowadays there is an active stage of mediation developing especially in schools and then in higher educational institutions. Mediation in education is an important part of mediation itself. The main goal of this process is prevention and solving of conflicts. This is an especially important innovative technology of ADR (alternative dispute resolution). Mediation has its rules, principles and procedures. This is not an easy way to manage a conflict, but an effective one. Today one of the problems is that the main principle of mediation - voluntariness is broken in some way. I.E. Petrova and E.S. Plot- 
nikova wrote in their article that "contrary to the requirements stated in the regulatory and legal documents and scientific principles in practice mediation becomes mandatory and unconditional for execution" (Petrova, Plotnikova, 2017: 145).

There are different types of mediation, which can be used in conflicts in higher educational institutions. For example, classic mediation and restorative mediation. At the same time there can be several type of mediators, i.e. mediator - professional and team members (students, lectures and so on) or so called stakeholders. Of course, the process involving professionals or non-professionals can have it peculiarities. "The classical model of mediation discusses the transition from positions to "true" human interests and the development with the help of the process of brainstorming a mutually beneficial solution" (Konovalov, 2014: 22). In this case, restoration of the relationships is not the main goal, but a desired result. At the same time restorative mediation deals with the "recognition and correction by the offender of the harm caused to the victim, the cessation of hostility, the restoration of understanding and destroyed relations" (Konovalov, 2014: 22). From the authors' point of view, restorative mediation has more preventive influence on the situation in campus and all social tension in the educational process. "The resolution of campus conflicts should improve the atmosphere for learning, teaching, research and service; it should maximise benefit and minimise costs; it should stress individual and institutional responsibility, respect collaboration, and accountability" (Yarn, 2014: 7).

One should mention that there is different experience in the way of mediation institutionalisation for its use in conflict prevention and resolution. One of them is the development of the Conflict Management System (CMS). Mediation is one of the elements of this system. It was developed especially for the University System of Georgia in (USG), which consists of 34 elements (universities and colleges), over 200,000 students and over 30,000 full-time employees (Yarn, 2014: 5). CMS consists of Boards of Regents: Chancellor's Office and
Advisory Committee and communicate with Individual Institutions. It has published a handbook with the main principles and instructions for the six-step model, which allows to create conflict resolution system for each unit of USG. System itself involves empirical studies (case studies, expert interviews etc.), collected quantitative data on mediation process, annual reports, mediation programmes. It implies education and training in conflict management theory and design, mediations itself. One should understand that there should be right situation for the creation of such a system. Many factors are important for the success of the CMS development. "An organisation may be incurring unsustainable costs from conflict, but may still not be able to initiate a design intervention without an alignment of the right circumstances with people who have the knowledge, motivation, and authority to initiate substantial systemic change" (Yarn, 2014: 14).

Another example of the conflict prevention and resolution is alternative dispute resolution (ADR) services. "These services range from preventative measures such as training and coaching to more formal reactive procedures such as conciliation, facilitation, mediation, and arbitration" (Katz, 2016: 176).

\section{Conclusion}

Thus, mediation and monitoring of conflict factors are important elements of the conflict management system in higher educational institutions. Monitoring helps to have up-todate information about all important indicators and mediation helps to manage conflict situations. "Conflict competence as a component of the professionalism of a university teacher is of great importance in the functioning of student society and more broadly in improving the quality of work of a general educational organisation" (Ryabinina, 2015: 53). This competence is good not only for the conflict management system but also for the teacher's work productivity. All elements of this system should be integrated into the life of a university and campus. High school needs support from the state and different organisations to develop this system. In order to succeed all the work in this field should be systematic and long standing. 


\section{References}

Banikina, S.V., Stepanov, E.I. (2006). Konflikty v sovremennoi shkole: izuchenie i upravlenie [Conflicts in today school: study and management]. Moscow: ComBook, 184 p.

Character development in schools and beyond (1992). Ed. Ryan, K., Lickona, T. Washington: The Council for Research in Values and Philosophy, $382 \mathrm{p}$.

Chepel, T.L., Abakirova, T.P. \& Samuylenko S.V. (2014). Effektivnost' obrazovatel'nogo protsessa v usloviiakh inkliuzivnoi praktiki: itogi monitoringovykh issledovanii [Efficiency of the educational process in terms of inclusive practices: the results of monitoring studies]. In Psihologicheskaia nauka i obrazovanie [Psychological Science and Education], 1, 33-41.

Chupris, A.S. (2016). Modeli mediatsii v usloviiakh obrazovatel'nykh uchrezhdenii [Models of mediation in the conditions of educational institutions]. In Vestnik Baltiiskogo federal'nogo universiteta im. I. Kanta. Seriia: Filologiia, pedagogika, psihologiia [Imanuil Kant Baltik University Vestnik. Series: Filology, Pedagogic, Psychology], 2, 108-113.

Clark, R.A. (2014). Correlation study: the effect of student-teacher rapport on high school student performance rate. Dissertation for the Degree Doctor of Education. Linchburg: Liberty University. 119 p., available at: http://digitalcommons.liberty.edu/cgi/viewcontent.cgi?article=1982\&context=doctoral (accessed 12.02.2017)

Hamre, B.K., Pianta, R.C. (2006). Student-teacher relationships as a source of support and risk in schools. In Children's Needs III: Development, Prevention, and Intervention. Bethesda, Maryland, 59-71.

Ignatova, E.S. (2014). Issledovanie konfliktogennykh faktorov pedagogicheskogo vzaimodeistviia V vuze [Research of conflictogenic factors in pedagogical interrelations in university]. In Diskussiia [Discussion], 10 (51), available at: http://journal-discussion.ru/publication.php?id=1222 (accessed 7.02.2017).

Karpov, A. (2015). (Sotsial'naia i ekzistentsial'naia ontologizatsiia obrazovaniia [Social and existential ontologisation of education]. In Voprosy filosofii [Issues of Philosophy], 1, 3-13.

Katz, N. (2016). Mediation and Dispute Resolution Services in Higher Education. In The Handbook of Mediation; edited by Alexia Georgakopoulos, available at: https:/www.researchgate.net/publication/315133569_MEDIATION_AND_DISPUTE_RESOLUTION_SERVICES_IN_HIGHER_EDUCATION (accessed 30.07.2019).

Kil'dyushov, O.V. (2016). Ot semi mudretsov do indeksa Hirsha: kak poschitat' filosofskuiu mysl' i chem eto chrevato [From the seven sages to Hirsch index: how to count philosophical thought and what this means]. In Sokrat (Socrat), 5, 28-31.

Klingel, S., Maffie, M. (2011). Conflict Management Systems in Higher Education: A Look at Mediation in Public Universities. Dispute Resolution Journal 66 (3): 12-17.

Konovalov, A.Y. (2014). Modeli raboty s konfliktami na osnove vosstanovitel'noi mediatsii v sisteme obrazovaniia [Mediation in the education system: a review of the experience of different countries]. In Psikhologicheskaya nauka i obrazovanie PSYEDU.ru [Psychological Science and Education PSYEDU.ru], 3, available at: http://psyedu.ru/journal/2014/3/Konovalov.phtml (accessed 30.08.2019).

Kuz'minov, Y.I. (2002). Obrazovanie i reforma [Education and reforms]. In Otechestvennye zapiski [Domestic Notes], 2, 7-29.

Kurbatova, M. (2016). Reforma vysshego obrazovaniia kak institutsional'nyi proekt rossiiskoi biurokratii: soderzhanie i posledstviia [Higher Education Reform as an Institutional Project of the Russian Bureaucracy: the Content and the Outcomes]. In Mir Rossii [The World of Russia], 4 (25), 59-86.

Petrova, I.E., Plotnikova, E.S. (2017). Problematizatsiia mediatsii v sisteme obrazovaniia Nizhegorodskoi oblasti [Problematisation of mediation in the education system of the Nizhny Novgorod region]. In Vestnik Nizhegorodskogo universiteta im. N.I. Lobachevskogo. Seriia: Social'nye nauki [Vestnik of Lobachevsky State University of Nizhni Novgorod. Series: Social Sciences], 4 (48), 144-150.

Ritzer, G. (2011). Makdonal'dizatsiia obshchestva [McDonalization of Society]. Moscow, Praxis, 592 p.

Ryabinina, E.V. (2015). Mediatsiia v rabote pedagoga vysshei shkoly [Mediation in the work of a university teacher]. In Obrazovanie i nauka [Education and science], 2 (121), 51-62. 
Ryapisov, N.A., Ryapisova, A.G. (2016). Monitoring effektivnosti inkliuzivnoi praktiki [Monitoring the effectiveness of inclusive practices]. In Vestnik Novosibirskogo gosudarstvennogo pedagogicheskogo universiteta [Novosibirsk State Pedagogical University Bulletin], 1, 7-22.

Shlykova, E.A. (2015). Otnoshenie k risku kak differentsiruiushchii faktor vybora sposoba vynuzhdennoi adaptatsii [Attitude to risk as a differentiating factor in the choice of the method of forced adaptation], available at: http://www.isras.ru/publ.html?id=4081 (accessed 29.05.2019).

Tambovtsev, V., Rozhdestvenskaya, I. (2014). Reforma vysshego obrazovaniia v Rossii: mezhdunarodnyi opyt i ekonomicheskaia teoriia [Higher education reform in Russia: international experience and economics]. In Voprosy ekonomiki [Issues of Economy], 5, 97-108.

Tavokin, E.P. (2012). Rossiiskoe obrazovanie pod pritselom reform [Russian education under pressure of reforms]. In Sotsiologicheskie issledovaniia [Sociological Studies], 8, 134-142.

Titova, N.L. (2008). Put' uspekha i neudach. Strategicheskoe razvitie rossiiskikh vuzov [The path of success and failure. Strategic development of Russian universities]. Moscow, MAX press, $279 \mathrm{p}$.

Vinogradova, E.V., Kozina, I.M. (2011). Otnoshenie sotrudnichestva i konflikta v predstavleniiakh rossiiskikh rabotnikov [Cooperation/conflict relationships as seen by Russian workers]. In Sotsiologicheskie issledovaniia [Sociological Studies], 9, 30-41.

Vinokurov, E.A., Potapov, V.V. (2004). Konflikt v predstavleniiakh studentov tekhnicheskogo vuza [The conflict in the views of a technical college students]. In Sotsial'nye konflikty: ekspertiza, prognozirovanie, tekhnologii razresheniia. Vyp. 19: Regional'naia konfliktologiia: konfliktogennye faktory $i$ ih vzaimodeistvie [Social conflicts: expertise, prognosis, resolution technologies. Release 19. Regional conflictology: conflict factors and its interaction]. Moscow, Editorial URSS, 241-247, 328 p.

Vol'chik, V.V. (2013). Reformirovanie rossiiskoi sistemy vysshego obrazovaniia: rol' mifov i institutov [Reformation of the Russian higher education system: the role of myths and institutions]. In Terra economicus, 2, 94-103.

Wyrick, A.J. (2011). Teacher-student relationships during adolescence: the role of parental involvement, behavioral characteristics, gender, and income. Electronic Theses and Dissertation. 114 p., available at: http://dx.doi.org/10.18297/etd/1599 (accessed 10.02.2017)

Yarn, D. (2014). Designing a Conflict Management System for Higher Education: A Case Study for Design in Integrative Organization. In Conflict Resolution Quarterly, xx (xx, xxxx), 1-25. 


\title{
Место медиации в системе мониторинга конфликтогенных факторов образовательной деятельности в условиях современных рисков
}

\author{
А.Г. Пинкевич, Г.П.Артемов \\ Санкт-Петербургский государственный университет \\ Российская Федераиия, Санкт-Петербург
}

\begin{abstract}
Аннотация. Статья посвящена анализу взаимосвязи медиации и мониторинга конфликтогенных факторов образовательного процесса.

Авторы рассматривают отдельные риски, с которыми связано сегодня образовательное пространство. Отдельное внимание уделено понятию управления конфликтом, его элементам.

Мониторинг конфликтогенных факторов проанализирован с точки зрения его основных составляющих, используемых методов сбора информации, значения соотношения качественных и количественных методов.

Медиация в последнее время заняла очень важное место в образовательном пространстве. Как переговоры с участием третьей стороны она является одним из способов предупреждения и урегулирования конфликтов. Авторы рассматривают различные модели использования медиации в образовательном процессе и включения ее в систему управления конфликтами.

Вместе с мониторингом конфликтогенных факторов образования медиация является неотъемлемым элементом системы управления конфликтами.
\end{abstract}

Ключевые слова: конфликтогенные факторы, медиация, образование, мониторинг, риски.

Исследование выполнено при поддержке Российского научного фонда (проект № 19-18-00115 «Риск-рефлексии в современных российских стратегиях управления конфликтом»).

Научное направление: 13.00.00 - педагогические науки. 